\title{
Recycled water is a promising new supply source
}

\author{
Henry J. Vaux, Jr.
}

During the first 8 decades of the 20th century, the primary means by which Californians addressed the problems of water scarcity was through the construction of dams and canals. Vast water projects allowed water to be brought from places where it was relatively plentiful to the drier areas where much of the population had settled.

But during the past few decades, construction of new water-supply projects has become a far less attractive means of addressing water scarcity than in the earlier years of the century. Due to higher relative costs for public works, environmental damages resulting from the construction and operation of impoundment reservoirs, and the fact that the most economical dam sites have already been developed, water planners have been forced to look for alternatives to meet the increasing demands which accompany population and economic growth.

Projections suggest that recycled water may be the most significant new source of additional surface-water supplies in California and throughout the semiarid West. Stringent regulations govern the quality of water that can be discharged from wastewater treatment plants into the ambient environment. Once water has been treated to meet these quality requirements, the cost of the additional treatments necessary to make it suitable for nondrinkable uses is quite modest (NRC 1994). The California Department of Water Resources (1998) estimates that more than 1 million acrefeet of suitable reclaimed water could be available for nonpotable uses by 2020.

Reclaimed water is already a significant source of supply for the irrigation of golf courses, public landscap- ing and freeway vegetation. In addition, a number of large groundwater recharge programs utilize reclaimed water. For example, the Orange County Water District's groundwater recharge program is one of the most sophisticated in the world (Mills et al. 1998). Orange County currently uses chemical clarification, recarbonation, granular-activated carbon and reverse osmosis to treat secondary wastewater to surpass drinking-water standards; that water is then injected into wells to prevent saltwater intrusion and replenish groundwater supplies.

Reclaimed water can also be used to irrigate commercial crops. The Israelis have pioneered its use to the point where recycled water accounts for more than $65 \%$ of the country's total agricultural use (Committee 1999).

The time when reclaimed water is used more widely for potable purposes may also be fast approaching. Several years ago, a National Research Council (NRC 1994) committee noted that the quality of recycled wastewater was better than that of existing water supplies in some locations. More recently, another NRC (1998) committee concluded that planned, indirect, potable reuse is viable when water quality is thoroughly assessed and monitored on an ongoing basis.

As the uses of reclaimed water are expanded, it will be important to mount education programs which fully inform the public about the benefits and risks. Much is known scientifically about wastewater reclamation, but unfortunately many proposals have been surrounded by emotional debates in which the science was neglected. Effective policies governing the use of reclaimed wastewater must be firmly based on the science of wastewater reclamation.

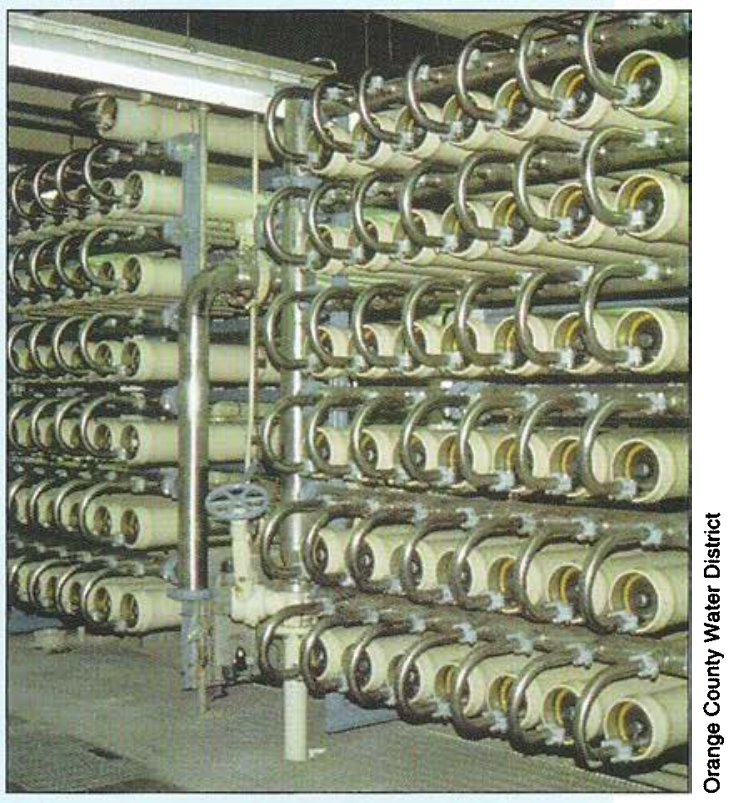

At Orange County Water District's Water Factory 21, state-of-the-art reverse osmosis treats wastewater by forcing it through a thin membrane to filter out minerals and contaminants. The cleansed water, which exceeds drinking-water standards, is injected into shallow aquifers to prevent seawater intrusion into the groundwater basin.

H.J. Vaux, Jr. is Associate Vice President, Division of Agriculture and Natural Resources, UC Office of the President, and Professor, Department of Environmental Sciences, UC Riverside.

\section{References}

California Department of Water Resources. 1998. California Water Plan Update. Bul. 160-98, vol. 1. Sacramento, CA.

[Committee] Committee on Sustainable Water Supplies for the Middle East. 1999. Water for the Future: The West Bank and Gaza Strip, Israel and Jordan. Washington, DC: National Academy Press. 226 p.

Mills WR, Bradford SM, Rigby M, Wehner MP. 1998. Groundwater recharge at the Orange County Water District. In: Asano T (ed.). Wastewater Reclamation and Reuse. Lancaster, PA: Technomic Publishing. p 1105-42.

National Research Council. 1994. Ground Water Recharge Using Waters of Impaired Quality. Commission on Geosciences, Environment and Resources. Washington, DC: National Academy Press. 283 p.

National Research Council. 1998. Issues in Potable Reuse. Committee to Evaluate the Viability of Augmenting Potable Water Supplies with Reclaimed Water. Washington, DC: National Academy Press. 263 p. 